\title{
Can hybrid poplar save industrial forestry in Canada?: A financial analysis in Alberta and policy considerations
}

\author{
by Jay A. Anderson ${ }^{1}$ and Martin K. Luckert ${ }^{2}$
}

\begin{abstract}
Intensifying forest management has the potential to alleviate pressures of competing land uses, maintain global competitiveness in the face of increasing exotic plantations, and increase the value of the boreal forest resource. Yet, such initiatives have largely been stymied in Canada's boreal regions because intensive forest management of native tree species is not financially viable. The yield curve estimation and financial analysis conducted in this paper, however, suggests intensive management of hybrid poplar in Alberta could be financially viable. The financial viability of such initiatives will depend heavily on the policies that governments use — such as priority-use zoning — to encourage or discourage such trends. But before reforming policy, decision-makers must trade off the environmental implications of industrial plantations of exotic species with the potential gains from priority-use zoning.
\end{abstract}

Key words: soil expectation value, optimal economic rotation, hybrid poplar, priority-use zoning, intensive forest management

\section{RÉSUMÉ}

Lintensification de l'aménagement forestier pourrait réduire les pressions compétitrices exercées dans un territoire donné, maintenir la compétitivité globale face aux plantations exotiques de plus en plus importantes et accroître la valeur de la ressource forestière boréale. Malgré tout, de telles initiatives ont été en grande partie vouées à l'échec dans les régions nordiques du Canada parce que l'aménagement forestier intensif des espèces indigènes s'avère non financièrement viable. L'estimation du rendement et l'analyse économique réalisées dans cet article, laissent entendre cependant que l'aménagement intensif de peupliers hybrides en Alberta pourrait être économiquement rentable. La viabilité économique de telles initiatives dépendra principalement des politiques utilisées par le gouvernement comme le zonage prioritaire du territoire, pour encourager ou décourager ce genre de tendance. Mais avant de reformer les politiques, les preneurs de décisions doivent trouver un équilibre entre les implications environnementales des plantations industrielles d'espèces exotiques et les gains potentiels tirés du zonage prioritaire du territoire.

Mots clés : valeur attendue du sol, cycle économique optimal, peuplier hybride, zonage prioritaire du territoire, aménagement forestier intensif

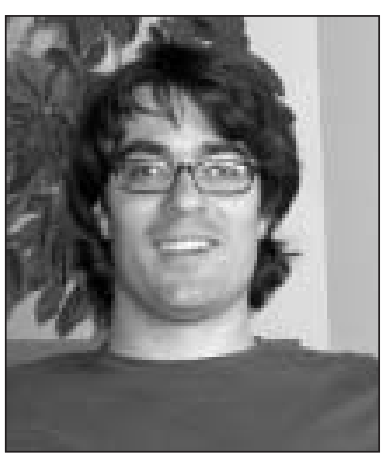

Jay A. Andersonn

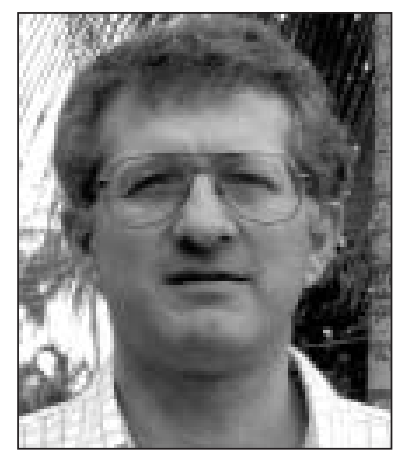

Martin K. Luckert

\section{Introduction: The perfect storm?}

Industrial forestry operations in Canada's boreal forest are currently facing a number of challenges. First, there is increasing competition among land uses and users. Interpreting historic rights of Aboriginal Peoples to forests is an ongoing process, in some cases having major potential implications

for industrial forestry (Stevenson and Webb 2003). Moreover, non-timber interests, including recreation and biodiversity values, are becoming increasingly influential in forest management plans. Along these lines, some believe current land use policies in Canada fail to protect enough land as biological reserves, thus leading to a decrease in biodiversity that may compromise future non-timber values (e.g., Hunter 1999, Larsson and Danell 2001). These concerns are increasingly being voiced by an international constituency that has had substantial success in curbing harvest in other jurisdictions, such as the United States (Limerick 2002). Meanwhile, some provincial forests are being heavily impacted by oil and gas production. For example, simulations for a study area in northeastern Alberta suggest that the energy and forestry industries could increase the density of human-origin edge from 1.8 to $8.0 \mathrm{~km} / \mathrm{km}^{2}$ (Schneider et al. 2003).

Second, the global forest industry appears to be undergoing significant changes. Forest fibre production is rapidly evolving from timber foraging to a system of agricultural cropping (Sedjo 1999). Although global harvest from industrial plantations was negligible as late as the 1950s, by 2000 it

${ }^{1}$ PhD Candidate, Department of Rural Economy, 515 GSB, University of Alberta, Edmonton, AB T6G 2H1. E-mail: jaya@ualberta.ca (corresponding author).

${ }^{2}$ Professor, Department of Rural Economy, University of Alberta, E-mail:marty.luckert@ualberta.ca 
had risen to an estimated $34 \%$, with $10 \%$ of this harvest made up of exotic tree species (Sedjo 2003). It is expected that the global share of timber from industrial plantations will rise to between 50 and $75 \%$ by the year 2030 (FAO 2000). If such predictions become reality, a firm's survival may depend on access to low-cost fibre from industrial plantations on main roads close to mills.

Third, the boreal forest does not represent a high-value fibre resource relative to other types of forests and other types of resources (e.g., oil and gas). Existing trees are small, relative to coastal forests, and growth rates are low (e.g., Sedjo 1999, Tomberlin and Buongiorno 2001). As such, stumpage fees collected by governments are frequently dwarfed by other revenue sources, and government costs of administering forestry operations on these lands sometimes exceed stumpage revenues that governments collect. For instance, in 2005-06 the Alberta government's oil and gas management expenses of $\$ 132$ million are estimated to yield revenues of $\$ 7.67$ billion from this sector; whereas government timber management expenses of $\$ 139$ million are only expected to yield stumpage revenues of $\$ 81$ million (Ministry of Finance 2005).

These three challenges lining up simultaneously have the potential to turn into the "perfect storm" for Canada's forest industry. In the United States, it only took a small subset of these conditions (i.e., spotted owls and below-cost timber sales) to reduce harvests on western federal forests in 1995 to $15 \%$ of what they were in 1988 (Wear and Murray 2004). Considering that Canada has approximately $95 \%$ of its forests on public lands, the suite of conditions currently brewing make the challenges facing the forest industry seem significant.

In the face of these challenges, one potential solution would be to intensify forest management. Such an approach is intuitively appealing as it could address all three problems. First, if intensified forest management delivers more cubic meters per hectare per year, then there would be the potential to maintain current harvest levels while freeing up forested land currently under industrial use for competing uses. It may also be argued that such a strategy is in line with global trends towards plantations and is necessary for the Canadian forest industry to maintain its global competitiveness. Finally, such practices could increase the value of the forest resource by increasing growth rates and locating timber on main roads close to mills.

The case for intensive forest management has spawned policy discussions regarding zoning policies that might promote this approach. For example, priority-use zoning systems, such as triad, ${ }^{3}$ have been touted as a means of maintaining jobs while at the same time increasing the protected landbase (e.g., Messier 2003). Priority-use zoning systems can have any number of different land use zones. An important concept of zoning is that by increasing timber productivity

\footnotetext{
${ }^{3}$ Triad is a priority-use zoning system consisting of three different management zones: intensive, extensive and protected. Intensive zones are managed as short-rotation industrial plantations; extensive zones are managed for multiple uses by incorporating native species under longer rotations; and protected zones are withdrawn from the industrial land base to act as biological reserves.
}

from intensive zones, it is possible to preserve more land in protected zones without eliminating jobs or output (Gladstone and Ledig 1990, Hunter and Calhoun 1996, Binkley 1997). Priority-use zoning acknowledges that a single hectare of land cannot be all things to all people. By managing all lands for all outputs, both timber and non-timber values may be inappropriately supplied, and management inputs may be inefficiently deployed (Vincent and Binkley 1993). Land use specialization may be a solution to these inefficiencies.

Unfortunately, financial considerations often spoil otherwise good ideas. Achieving a financially viable intensive zone in the boreal forest is difficult at the stand level (Rodrigues et al. 1998) and may condemn priority-use zoning. The large initial investment required in relation to the relatively low productivity gained from native species results in negative soil expectation values (SEVs) (Rodrigues et al. 1998), thus making such investments financially unviable. Accordingly, it may be difficult to justify allocating land to an intensive zone using financially unviable silvicultural systems. There are, however, many silvicultural systems, and thus many ways to implement priority-use zoning. Intensive zones may require trees that grow fast enough to give firms the financial incentive to make the large capital investments required for intensive forest management. Hybridized varieties of poplar, aspen and willow may be those trees (Weih 2004). Some researchers have predicted the $21^{\text {st }}$ century to be the "era of tree domestication," and that "poplar will lead the way" (Bradshaw and Strauss 2001). Much of the interest in poplar results from its vegetative propagation abilities. With stem cuttings, superior hybrids can be easily and quickly cloned and, within a short time, made available for planting on a large scale (Heilman 1999). But the most recent empirical study we found to support this opinion - a paper by Peterson et al. (1970) - is over thirty years old and does not consider financial viability.

One way to gain insights into the financial viability of hybrid poplars for fibre production is to consider potential areas of the expansion of hybrid poplar plantations and to see what forest companies are doing. Tardif (1994) reports that of Canada's 67.8 million hectares of agricultural lands, 21 million hectares are considered to be marginal lands (i.e., of borderline profitability when used for agriculture) and may therefore be considered usable for hybrid poplar. ${ }^{4}$ Close to $80 \%$ of these marginal areas are located in British Columbia and Alberta. Yet few firms are pursuing the global trend of establishing fast-growing industrial plantations. For example, we know of only one firm in Alberta, Alberta-Pacific Forest Industries Inc., that is operationally (i.e., not for research purposes) establishing private-land plantations of exotic species, with plans to establish 25000 hectares of hybrid poplar plantations by 2020 (Thomas and Kaiser 2003). But the paucity of exotic plantations may not result from financial reasons alone. For example, Alberta has regulations strictly constrain-

\footnotetext{
${ }^{4}$ Hybrid poplar may not only be relegated to the less productive agricultural lands. But as will be shown in the financial analysis, the land rents payable to lease agricultural land can be substantial. Higher quality agricultural land would attract higher rental rates, which could make it difficult for hybrid poplar to yield a positive return.
} 
ing the use of exotic species on public land, ${ }^{5}$ as well as preventing foreign firms from purchasing private land for timber production. ${ }^{6}$ Therefore, it is unclear to what degree financial considerations and/or policy constraints are impeding the spread of plantations.

In order to inform the more general question of what hybrid poplar might do for the Canadian forest industry, this paper begins with a stand-level financial analysis. Because the collection of yield data for hybrid poplar has largely been limited to the Prairie Provinces, and because commercial operations of hybrid poplar have largely been focused in Alberta, we develop our financial analysis based on an Alberta case study. Since this paper is a financial analysis, it assumes the sole benefit of concern is commercial timber and no considerations are made for non-timber values. We then present a number of potential policy considerations that could influence the future role that hybrid poplar plantations may play in Alberta and across Canada.

\section{Methods}

Although hybrid poplar has only recently attracted the attention of Canadian forestry firms, the Prairie Farm Rehabilitation Administration (PFRA), a division of Agriculture and Agri-Food Canada, has been conducting research on hybrid poplars for over 25 years. In this section, PFRA data are used to estimate a yield curve for hybrid poplar in the western Canadian boreal regions. This yield curve is then used in a stand-level model to calculate optimal economic rotations (OERs) and associated SEVs. The Results section contains analysis of the sensitivity of the OERs and SEVs to changing net stumpage values, land rental costs, silviculture costs, discount rates, and stand yield parameters.

\section{Data collection}

To our knowledge, the best source of long-term growth and yield data for Canada's western boreal regions comes from the PFRA (2001), which has conducted numerous growth trials where rooted cuttings of various hybrid poplar clones were planted at different locations throughout Saskatchewan. These trials are located between 102 and 110 degrees longitude west of the Greenwich meridian and between 49 and 60 degrees latitude north of the equator. Each year, western Canadian boreal regions usually receive 350 to $450 \mathrm{~mm}$ of rainfall and experience 140 to 170 frost-free days (Environment Canada 2004).

In 2001, PFRA measured hybrid poplar stands in 4-, 15and 25-year age classes. The data from these measurements were used to estimate the yield curve for this paper. The PFRA's objective was to compare the performance of different clones. Thus, for each of the three different age classes, the

\footnotetext{
${ }^{5}$ Forests Act, Timber Management Regulations 60/73: 144.2 The Minister may establish rules governing the source and type of tree seed and vegetative propagules used to reforest public land. AR 60/91 s26;153/97 and Standards for Tree Improvement in Alberta (Ref. T/037): Provides standards for deployment of improved trees onto public land.

${ }^{6}$ Agricultural and Recreational Land Ownership Act, Foreign Ownership of Land Regulations 160/79: 5(1) An ineligible person or foreign controlled corporation may take or acquire, directly or indirectly, an interest in... land consisting of not more than 2 parcels containing, in the aggregate, not more than 20 acres.
}

PFRA measured DBH, height and percent survival and averaged the results for each of the clones evaluated in the particular study. ${ }^{7}$ This averaging resulted in a single value for $\mathrm{DBH}$, height and percent survival for each different clone in each age class.

The four-year age class study, which was conducted at five different locations in Saskatchewan, was planted at various densities to determine the optimal stocking level for forestry applications. The 15-year age class study, which also incorporated conditions similar to forestry applications, entailed monitoring trees of 11 different clones planted in three different locations in Saskatchewan. This study had four outlier clones that suffered unusually high mortality. These outlier clones were not used in the yield curve estimation based on the assumption that PFRA conducted these projects as breeding trials, and these poorly performing hybrids would likely be eliminated from future breeding. Finally, the 25-year age class study was a three-row shelterbelt application with spacing equivalent to a 1000-stem-per-hectare planting. In this case, rooted cuttings of 15 clones were planted in one location near Indian Head, Saskatchewan. Once again, some of the clones in this study showed unusually poor performance, and so six of the 15 clones that were shorter than the average 15year height were eliminated from the results.

Another complication is that not all of the stands were planted at the same density. An average stocking level of 1000 stems per hectare was used, since this was the target density for the 15- and 25-year studies.

It is important to note that the PFRA measurements were not obtained by following the same stand of trees through their life cycle, as would occur using permanent sample plots. Instead, the PFRA data are one-time measurements of a group of stands in the same age class. This means that the data for each age class are not gathered from the same trees, or even from the same sites. In using these data we are unable to isolate the effects of a number of potential explanatory variables, such as local site productivity and method of controlling competition, which could influence the yield curve. For all these reasons, we were unable to estimate yield curves for individual clones. Given the data that are available, we estimate a yield curve that may be considered to be an aggregate representation of hybrid poplar performance in western Canadian boreal regions.

\section{Stem volume calculation}

Before a growth curve could be estimated, the average volume for the three different age classes had to be calculated. To do this, the following hybrid poplar stem volume equation developed by the Ontario Ministry of Natural Resources (OMNR 1991) was used:

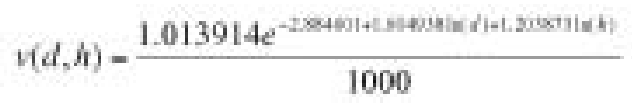

where $v=$ stem volume in cubic meters, $d=\mathrm{DBH}$ in centimetres, and $h=$ height of the tree in metres.

This equation is based on 407 observations of hybrid poplar growing in eastern Ontario, and has an $\mathrm{R}^{2}$ of 0.9877

${ }^{7} \mathrm{DBH}$ and percent survival was not evaluated in the four-year age class. 
TABLE 1. Complete data set with estimated stem and stand volumes for each clone. *

\begin{tabular}{|c|c|c|c|c|c|c|}
\hline Age Class & Clone & $\begin{array}{c}\text { Avg. } \\
\text { Ht. (m) }\end{array}$ & $\begin{array}{c}\text { Avg. } \\
\text { DBH }(\mathrm{cm})\end{array}$ & $\begin{array}{l}\text { Est. Stem } \\
\text { Vol. }\left(\mathrm{m}^{3}\right)\end{array}$ & $\begin{array}{l}\text { Percent } \\
\text { Survival } ~\end{array}$ & $\begin{array}{c}\text { Stand Vol. } \\
\left(\mathrm{m}^{3} / \mathrm{ha}\right)\end{array}$ \\
\hline \multirow[t]{6}{*}{ 4-year } & Walker & 4.6 & 3 & 0.002 & $100 \%$ & 2.07 \\
\hline & Walker & 4.4 & 3 & 0.002 & $100 \%$ & 1.97 \\
\hline & Walker & 4.3 & 3 & 0.002 & $100 \%$ & 1.91 \\
\hline & Assiniboine & 3.8 & 3 & 0.002 & $100 \%$ & 1.65 \\
\hline & Assiniboine & 3.3 & 3 & 0.001 & $100 \%$ & 1.39 \\
\hline & Assiniboine & 3.0 & 3 & 0.001 & $100 \%$ & 1.24 \\
\hline \multirow{3}{*}{\multicolumn{2}{|c|}{$\begin{array}{l}\text { Average } \\
\text { Std. Dev. } \\
\text { 95\% C.I. }\end{array}$}} & 3.9 & 3.0 & 0.002 & $100 \%$ & 1.71 \\
\hline & & 0.6 & 0.0 & 0.000 & 0.0 & 0.34 \\
\hline & & & & & & \pm 0.35 \\
\hline \multirow[t]{26}{*}{ 15-year } & Walker & 12.6 & 18.2 & 0.126 & $83 \%$ & 104.56 \\
\hline & Assiniboine & 12.7 & 16.8 & 0.112 & $89 \%$ & 99.54 \\
\hline & Manitou & 13.2 & 21.2 & 0.170 & $100 \%$ & 170.20 \\
\hline & Northwest & 12.1 & 19 & 0.129 & $79 \%$ & 101.56 \\
\hline & $38 \mathrm{P} 38$ & 12.7 & 23.3 & 0.189 & $94 \%$ & 177.71 \\
\hline & Plains Cott. ATNHC & 11.2 & 20.1 & 0.128 & $89 \%$ & 114.10 \\
\hline & Brooks \#6 & 1.7 & 21.9 & 0.155 & $78 \%$ & 120.95 \\
\hline & $71-146$ & 9.3 & 13.4 & 0.053 & $67 \%$ & 35.82 \\
\hline & $71-71$ & 10.1 & 12.6 & 0.053 & $89 \%$ & 47.61 \\
\hline & Griffin & 10 & 15.3 & 0.072 & $61 \%$ & 44.03 \\
\hline & Walker & 16.9 & 21.2 & 0.229 & $100 \%$ & 229.16 \\
\hline & Assiniboine & 15.6 & 19.3 & 0.179 & $100 \%$ & 179.00 \\
\hline & Northwest & 14.3 & 20.2 & 0.173 & $100 \%$ & 173.43 \\
\hline & $38 \mathrm{P} 38$ & 15.6 & 25.6 & 0.282 & $94 \%$ & 264.77 \\
\hline & Plains Cott. ATNHC & 13.7 & 18.9 & 0.148 & $94 \%$ & 139.15 \\
\hline & Brooks \#6 & 13.7 & 17.1 & 0.126 & $89 \%$ & 112.20 \\
\hline & $71-146$ & 10.1 & 13.7 & 0.061 & $89 \%$ & 54.46 \\
\hline & $71-71$ & 12.2 & 13 & 0.071 & $100 \%$ & 70.61 \\
\hline & $71-172$ & 14.3 & 19.1 & 0.159 & $78 \%$ & 123.65 \\
\hline & Walker & 15.1 & 19.4 & 0.174 & $89 \%$ & 154.46 \\
\hline & Assiniboine & 15.4 & 17.9 & 0.156 & $67 \%$ & 104.64 \\
\hline & Manitou & 12.4 & 18.1 & 0.122 & $72 \%$ & 88.19 \\
\hline & Northwest & 12.5 & 17.1 & 0.113 & $83 \%$ & 93.70 \\
\hline & Plains Cott. ATNHC & 11.5 & 18.1 & 0.112 & $79 \%$ & 88.37 \\
\hline & Brooks \#6 & 11.2 & 17.1 & 0.099 & $83 \%$ & 82.10 \\
\hline & $71-71$ & 11.6 & 14.2 & 0.077 & $78 \%$ & 59.72 \\
\hline \multirow{3}{*}{\multicolumn{2}{|c|}{$\begin{array}{l}\text { Average } \\
\text { Std. Dev. } \\
\text { 95\% C.I. }\end{array}$}} & 12.76 & 18.15 & 0.13 & $86 \%$ & 116.68 \\
\hline & & 1.96 & 3.20 & 0.05 & 0.11 & 56.67 \\
\hline & & & & & & \pm 22.89 \\
\hline \multirow[t]{9}{*}{ 25-year } & Hill & 15.1 & 25.6 & 0.271 & $100 \%$ & 270.84 \\
\hline & Walker & 13.3 & 20.8 & 0.167 & $86 \%$ & 142.76 \\
\hline & Northwest & 13.6 & 26.1 & 0.246 & $79 \%$ & 193.60 \\
\hline & P. deltoides 709 & 15.3 & 28.2 & 0.321 & $64 \%$ & 206.64 \\
\hline & P.x berolinensis & 13 & 20.7 & 0.161 & $43 \%$ & 68.99 \\
\hline & Tristis \#1 & 13 & 20.2 & 0.155 & $71 \%$ & 110.40 \\
\hline & Brooks \#4 & 14.6 & 27 & 0.283 & $86 \%$ & 242.77 \\
\hline & Grandifolia & 14.9 & 26.1 & 0.275 & $93 \%$ & 255.41 \\
\hline & nigra viadri & 16.1 & 23.7 & 0.259 & $71 \%$ & 184.58 \\
\hline \multirow{3}{*}{\multicolumn{2}{|c|}{$\begin{array}{l}\text { Average } \\
\text { Std. Dev. } \\
\text { 95\% C.I. }\end{array}$}} & 14.32 & 24.27 & 0.24 & $77 \%$ & 186.22 \\
\hline & & 1.13 & 3.02 & 0.06 & 0.17 & 68.01 \\
\hline & & & & & & \pm 52.28 \\
\hline
\end{tabular}

* for some trials we were unable to locate the plot sizes in the PFRA literature

$\sim$ percent survival for the 4 -year age class assumed to be $100 \%$ 
Table 2. Optimization results in determining the parameters for the different growth functions.

\begin{tabular}{|c|c|c|c|c|c|c|c|c|c|c|c|}
\hline \multicolumn{4}{|c|}{ CHAPMAN-RICHARDS } & \multicolumn{4}{|c|}{ LUNDKVIST-KORF } & \multicolumn{4}{|c|}{ McDILL-AMATEIS } \\
\hline \multicolumn{4}{|c|}{$\mathrm{v}(\mathrm{t})=\mathrm{A}\left(1-\mathrm{e}^{-\mathrm{bt}}\right)^{\mathrm{c}}$} & \multicolumn{4}{|c|}{$\mathrm{v}(\mathrm{t})=\mathrm{Ae}^{-(\mathrm{k} / \mathrm{t} \wedge \mathrm{n})}$} & \multicolumn{4}{|c|}{$\mathrm{v}_{2}=\mathrm{A} /\left[1-\left(1-\left(\mathrm{A} / \mathrm{v}_{1}\right)\right)^{*}\left(\mathrm{t}_{1} / \mathrm{t}_{2}\right)^{\mathrm{a}}\right]$} \\
\hline & $A=$ & 275 & & & $A=$ & 275 & & & $A=$ & 275 & \\
\hline & $\mathrm{b}=$ & 0.1 & & & $\mathrm{k}=$ & 49.7 & & & $=$ & 3.6 & \\
\hline & $c=$ & 1.9 & & & $\mathrm{n}=$ & 1.5 & & & & & \\
\hline $\begin{array}{l}\text { Age } \\
\text { Class }\end{array}$ & $\begin{array}{c}\text { Empirical } \\
\operatorname{Vol}\left(\mathrm{m}^{3} / \mathrm{ha}\right)\end{array}$ & $\begin{array}{l}\text { Estimated } \\
\operatorname{Vol}\left(\mathrm{m}^{3} / \mathrm{ha}\right)\end{array}$ & $\begin{array}{l}\text { Absolute } \\
\text { Variation }\end{array}$ & $\begin{array}{l}\text { Age } \\
\text { Class }\end{array}$ & $\begin{array}{c}\text { Empirical } \\
\operatorname{Vol}\left(\mathrm{m}^{3} / \mathrm{ha}\right)\end{array}$ & $\begin{array}{c}\text { Estimated } \\
\operatorname{Vol}\left(\mathrm{m}^{3} / \mathrm{ha}\right)\end{array}$ & $\begin{array}{l}\text { Absolute } \\
\text { Variation }\end{array}$ & $\begin{array}{l}\text { Age } \\
\text { Class }\end{array}$ & $\begin{array}{c}\text { Empirical } \\
\operatorname{Vol}\left(\mathrm{m}^{3} / \mathrm{ha}\right)\end{array}$ & $\begin{array}{l}\text { Estimated } \\
\operatorname{Vol}\left(\mathrm{m}^{3} / \mathrm{ha}\right)\end{array}$ & $\begin{array}{l}\text { Absolute } \\
\text { Variation }\end{array}$ \\
\hline 4 & 1.7 & 17.3 & 15.6 & 4 & 1.7 & 0.5 & 1.2 & 4 & 1.7 & 0.0 & 1.7 \\
\hline 15 & 116.7 & 116.0 & 0.7 & 15 & 116.7 & 116.7 & 0.0 & 15 & 116.7 & 116.7 & 0.0 \\
\hline \multirow[t]{2}{*}{25} & 186.2 & 186.2 & 0.0 & 25 & 186.2 & 184.6 & 1.6 & 25 & 186.2 & 226.4 & 40.2 \\
\hline & & min Total & 16.3 & & & min Total & 2.8 & & & min Total & 41.9 \\
\hline
\end{tabular}

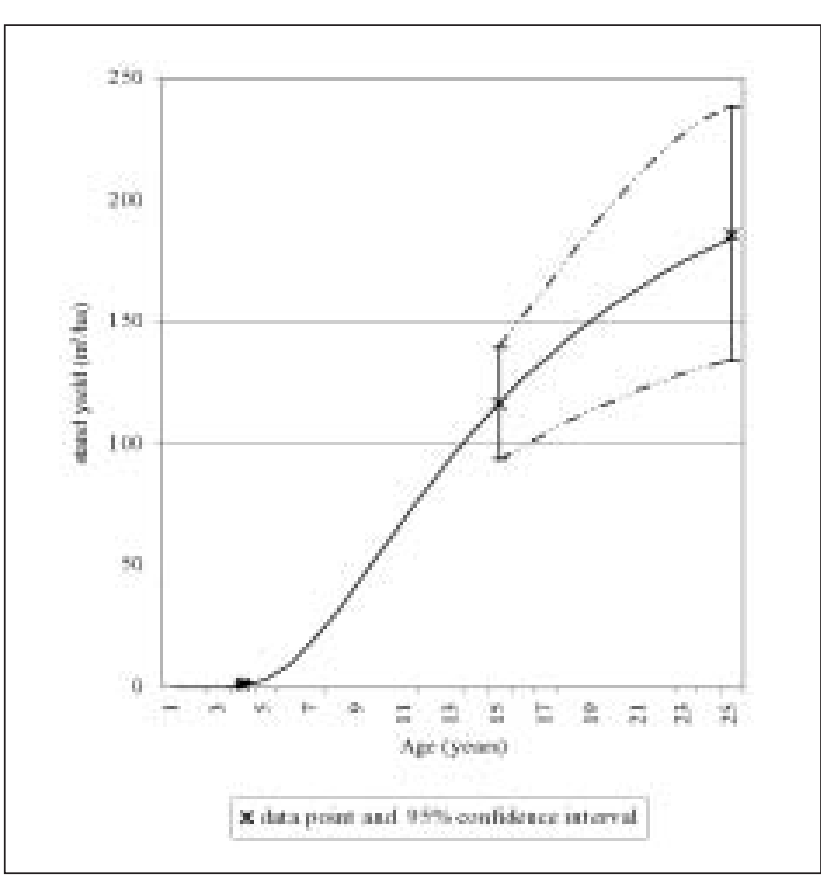

Fig. 1. Estimated stand yield curve for hybrid poplar versus actual data points with 95\% confidence intervals. and a root mean square of 0.0986 (OMNR 1991). Using this equation the stem volume was calculated for each clone measured in the PFRA studies. Since the DBH of the fouryear age class was not measured, an estimate of $3 \mathrm{~cm}$ was used based on the observation that hybrid poplars normally experience diameter growth of approximately $1 \mathrm{~cm}$ per year (Barb Thomas, Adjunct Professor, Department of Renewable Resources, University of Alberta, personal communication, 6 May 2004). The low volume of the trees at this age makes this assumption of little importance to estimating the stand yield curve.

\section{Stand volume calculation}

The average stem density of the PFRA trials was approximately 1000 stems per hectare. Since the percent survival in the four-year age class was not measured, it was assumed to be $100 \%$. Once again, the low volume of the stand at this age makes this assumption of little importance. Survival rates were measured for the other two age classes. By multiplying the individual clone's survival rate (which for all clones averaged $86 \%$ and $77 \%$ for the 15 - and 25 -year age classes, respectively) by the initial density of 1000 stems per hectare, the number of surviving stems per hectare could be calculated for each clone. Then, multiplying this value by the value for stem volume obtained from [eq. 1] gives the stand volume in cubic

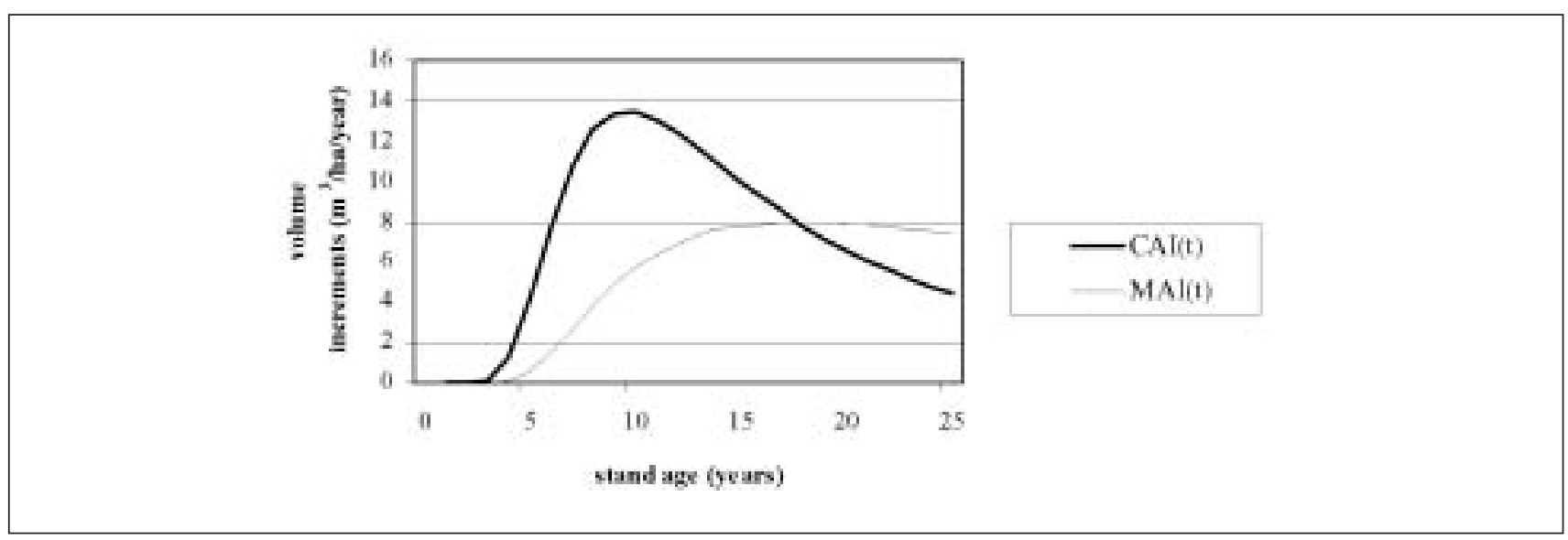

Fig. 2. CAl and MAl at different stand ages. 
meters per hectare for that particular clone. To come up with a single stand volume for each of the three age classes, the stand volume values for each clone were averaged for the particular age class. The complete dataset is listed in Table 1.

\section{Yield curve estimation}

The average values from the three different sampling years were then used to derive a mathematical function that estimates the volume of a stand of hybrid poplar as it ages. Three different functional forms were analyzed: (i) the ChapmanRichards growth function, (ii) the Lundkvist-Korf growth function, and (iii) the McDill-Amateis growth function. To attempt to find the best functional form, the solver within Microsoft Excel was used to estimate the unknown parameters that minimize the sum of the absolute variations between the estimated yield and the empirical observation at the three age classes. The results of these optimizations are listed in Table 2, which suggests that the Lundkvist-Korf growth function provides estimates closest to the empirical data. Therefore, the final form of the growth function used in this paper for the remaining analysis is:

$$
v(r)=275 e^{-\left(\frac{48.7}{15}\right)}
$$

For a visual representation of how well this function "fits" the average stand volumes measured for the three age classes, the curve for this function is graphed in Fig. 1 on top of the three empirical data points and their respective 95\% confidence intervals. As can be seen, the yield curve very closely estimates all three empirical data points. Dashed lines indicate how the growth function might intersect the upper and lower 95\% confidence intervals. Values from these upper and lower growth functions will be used in the Results section to provide bounds for conducting sensitivity analysis.

Fig. 2 shows the average growth, represented by the mean annual increment (MAI), and the marginal growth, represented by current annual increment (CAI). The two curves intersect at the sustained yield rotation age of 19 years, which is the point where MAI is maximized. ${ }^{8}$

\section{Stand-Level Optimal Economic Rotation Model General model assumptions}

Timber used for producing pulp and strand-board is not normally valued on wood size. Accordingly, we assume that the real stumpage values per cubic meter of merchantable timber remain constant as trees grow.

When determining merchantable volume, three factors should be considered: (i) bark thickness, (ii) stump height, and (iii) the non-merchantable tree top. Bark thickness of short-rotation poplar has been found to be negligible (Benbrahim and Gavaland 2003). We also assume that the cultivated soil in plantations allow harvesting equipment to harvest the stumps at ground level, making wastage from

\footnotetext{
${ }^{8}$ As will be shown in the Results section, hybrid poplar under the base case assumptions has an optimal economic rotation (OER) of 19 years, which is the same as the sustained yield rotation (as shown by the point of intersection between the MAI and CAI functions in Fig. 2). This is unusual for the boreal forest, where the long periods required for native species to grow typically leads to OERs being shorter than maximum MAI-based rotations.
}

stumps also negligible. In determining the wastage from the non-merchantable tree top, a merchantable top diameter of $7 \mathrm{~cm}$ is assumed. To estimate the length of each non-merchantable top, we use the ratio of average basal diameter to average height ${ }^{9}$ for the 15- and 25 -year age classes, which is $1.7 \mathrm{~cm} / \mathrm{m}$. Dividing the top diameter of $7 \mathrm{~cm}$ by this ratio gives an estimated top length of $4.1 \mathrm{~m}$. Since it can be assumed that stems are conical close to the top (Kozak 1988, Saint André et al. 1999), inserting the top diameter and length into the volume equation for a cone, reveals an estimated non-merchantable top volume of $0.005 \mathrm{~m}^{3} /$ tree.

It is assumed that this wastage is equal for all trees, regardless of age. Multiplying this value by the stand density equals the total wastage per hectare, which when deducted from the yield curve gives the net stand volume. The following financial analysis is based on net stand volume.

\section{Model setup}

The optimal economic rotation (OER) is the stand age where the marginal return from allowing the stand to grow another year equals the opportunity cost of the capital that would be generated from harvesting the current crop and regenerating the site, thereby maximizing the value of the forest land (e.g., Pearse 1990). This paper uses a continuous-time version of the Faustmann formula, which determines the stand age, $t$, which is the OER for maximizing the SEV of an infinite stream of forest rotations. The equation is structured as follows:

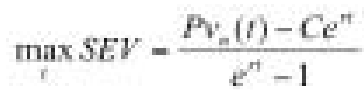

where

[4] $\quad C=\sum_{i=0}^{T} S_{r}^{\text {Fr }}$

$P=$ the real net stumpage value per $\mathrm{m}^{3}$ of the timber (i.e., gate price minus harvest and haul costs)

$v_{n}(t)=$ the net stand volume $\left(\mathrm{m}^{3}\right)$ per hectare as a function of age

$r=$ the real interest rate

$S_{t}{ }^{\mathrm{PV}}=$ the real present value per hectare of silvicultural costs incurred at time $t$

$T=$ that value of $t$ that maximizes the value of SEV (i.e., the optimal economic rotation)

SEV represents the value of the land to the landowner when the land is used for growing hybrid poplar. As such, it can be compared to agricultural values of land to see how competitive hybrid poplar may be. But since many of the forestry firms currently contemplating hybrid poplar are foreignowned and cannot purchase land, the model must consider that firms make silvicultural investments without being landowners. Therefore, the model must be restructured such that firms may choose to rent the required land at a fixed annual cost. In this case, the landowner does not realize the returns from selling the hybrid poplar, as is implicit in SEV. Instead, the landowner contractually agrees to a real annual land rent that remains constant throughout the rotation period. This annual land rent may be considered analogous to the timber dues that the government charges to forestry firms

\footnotetext{
${ }^{9}$ The average total height is reduced by $1.3 \mathrm{~m}$ (breast height) to estimate the height as it would relate to the basal diameter.
} 
for timber harvested from public land. Yet, such payments differ from current stumpage systems, where firms pay "stock rents" for harvesting existing mature timber, in that the tenants now pay "land productivity rents" for the value of the land in its ability to produce future timber (Luckert and Bernard 1993).

In order to assess the financial viability to the forestry firm, we must calculate the value that considers rental payments to the landowner. To do this we add rental costs to [eq. 4] to get:

$$
C=\sum_{r=0}^{T} S_{t}^{N T}+\sum_{r=0}^{T} R_{T}^{r r}
$$

where $R_{t}^{\mathrm{PV}}=$ the real present value per hectare of land rent paid by the forestry firm to the landowner at time $t$.

Substituting [eq. 5] into [eq. 3] we get:

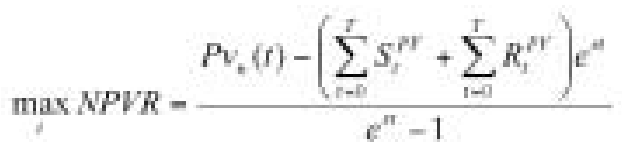

This maximized value represents the land value to a landrenting forestry firm. Since it is different than the original SEV in [eq. 3], we define this new land value as the net present value to the land renter (NPVR). The fact that the forestry firm does not own the land may make infinite-period discounting seem counter-intuitive. But firms conduct plantation forestry to provide long-term timber supply, and are therefore likely to consider multiple rotations, even if operating on leased land. Hence, we treat the decision of whether or not to conduct plantation forestry as a long-term decision that warrants infinite-period discounting.

In addition to expressing the financial viability as both an SEV and an NPVR, we also provide additional financial information by calculating the internal rate of return (IRR) and the benefit-cost ratio $(\mathrm{B} / \mathrm{C})$ based on the NPVR values. Here, the IRR is defined as the interest rate such that the NPVR is equal to zero. It can be interpreted as the percentage rate that a silvicultural investment grows to produce future benefits (Pearse 1990). The real IRR is calculated from the above model finding the $r$ that makes NPVR $=0$. The $\mathrm{B} / \mathrm{C}$ is the ratio of the present value of the timber to the present value of the total costs (including rent paid to the landowner). It can be interpreted as the benefits generated per dollar invested (Pearse 1990).

To account for the large number of exogenous variables in the model, a base case was developed using variables applicable to a typical pulp mill in Alberta. Then, to conduct sensitivity analysis, ten additional scenarios were chosen in which all of the variables in the base case were held constant except one - i.e., in each scenario we isolate one variable from the base case assumptions and assess the sensitivity of the IRR to a change in this variable. For these ten scenarios to be defined, we must first assume base case values for each exogenous variable. This base case represents our best estimate regarding the current values of the variables in the model. We then estimate a change for each exogenous variable upon which we wish to conduct sensitivity analysis.

\section{Base case and sensitivity analysis assumptions}

Calculating values with [eq. 6] requires values for the following variables:
Net stumpage value $(P)$

This value represents the timber price received at the gate by the land-renting forestry firm minus all costs associated with harvesting and hauling the timber to the mill. The average non-conifer pulpwood value for Alberta in the third quarter of the year 2000 was $\$ 45.88 / \mathrm{m}^{3}$ (WRI 2000). After adjusting for the $2 \%$ average annual core inflation that occurred between 2000 and 2004 (Bank of Canada 2004), the 2004 gate price would be $\$ 48.69 / \mathrm{m}^{3}$. Harvesting is assumed to cost $\$ 15 / \mathrm{m}^{3}$ and load and haul are assumed to cost $\$ 5 / \mathrm{m}^{3}$ (approximately a two-hour cycle time) (Andrew Swan, Forest Operations Consultant, Edmonton, Alberta, personal communication, 17 August 2004). Deducting these harvest and haul costs yields a net stumpage value $(P)$ of $\$ 28.69 / \mathrm{m}^{3}$.

While the average fibre cost for northern bleached softwood kraft pulp ${ }^{10}$ between 1990 and 2003 was approximately US $\$ 220$ per tonne of pulp, the high was approximately US $\$ 280$ and the low US $\$ 170$ (WRI 2003); a range of almost $25 \%$. Thus, the historical volatility of pulpwood fibre costs suggests $25 \%$ as an appropriate factor for conducting sensitivity analysis.

\section{Land rent $(R)$}

Alberta-Pacific Forest Industries Inc. (Al-Pac) is currently entering into agreements with local landowners to rent land for $\$ 62 /$ ha/year (Thomas and Kaiser 2003). In conducting sensitivity analysis, the land rent was increased and decreased by $25 \%$.

\section{Silviculture costs $(S)$}

$\mathrm{Al}-\mathrm{Pac}$ is one of the few boreal forestry firms establishing hybrid poplar plantations on an operational basis, and has found the following silvicultural cost assumptions to be valid (Thomas and Kaiser 2003):

Year 0: site preparation and planting:

Year 1: cultivation and herbicide:

Year 2: cultivation and herbicide:

Year 3: cultivation and herbicide:

Year 4: cultivation and herbicide:

$$
\begin{aligned}
& \$ 950 / \mathrm{ha} \\
& \$ 77 / \mathrm{ha} \\
& \$ 77 / \mathrm{ha} \\
& \$ 77 / \mathrm{ha} \\
& \$ 77 / \mathrm{ha}
\end{aligned}
$$

When all costs are discounted to year 0 and summed, the total present value $(\mathrm{PV})$ of silviculture costs over one rotation is $\$ 1231 / \mathrm{ha}$. In conducting sensitivity analysis, the silviculture cost was increased and decreased by $25 \%$.

\section{Real interest rate $(r)$}

In choosing the appropriate interest rate for private longterm forestry applications, ${ }^{11}$ it is important to consider the opportunity cost of not investing in alternative investments. A good benchmark is the Aaa corporate bond yields in the United States, which between 1970 and 1999 yielded an average nominal interest rate of $9.0 \%$ in the wake of average inflation of 5.3\% (Buongiorno and Gilless 2003). Since real dollars are used exclusively in this model, the real rate of return must be used as a discount rate. The real rate of return is the difference between the nominal rate and the inflation rate, which is $3.7 \%$. In conducting sensitivity analysis, the real interest rate was increased and decreased by 1.5 percentage points.

\footnotetext{
${ }^{10}$ Long run hardwood fibre costs not available.

${ }^{11}$ There are conflicting views on what interest rate should be used for analyzing silvicultural investments. While this study uses a standard benchmark for private investors, there are arguments that favour a lower "social" interest rate (e.g., Harou 1985).
} 
Stand yield parameters $(A, k$ and $n)$

The base case uses the estimation from Table 2, which for the Lundkvist-Korf functional form derived the parameters $A=$ $275, k=49.7$ and $n=1.5$. There is, however, current research using selective breeding and transgenic technologies to further increase growth rates by incorporating insect-, disease-, and herbicide-resistance (Pullman et al. 1998). When using the yield function estimated in this paper, another important factor to consider is the degree of variability in the measurements between clones, as well as the large 95\% confidence intervals resulting from this variation. Recall from Fig. 1 the dashed lines used to estimate yield functions that would intersect the upper and lower bounds of these confidence intervals. These functions were used to set the upper and lower bounds for the sensitivity analysis, which at year 20 are a $27 \%$ increase and a $24 \%$ decrease in stand volume, respectively.

\section{Results}

The results of the sensitivity analysis are summarized in Table 3. Recall that the SEV values indicate the value of bare agricultural land for use in growing hybrid poplar, and may be compared with current agricultural land values to assess how competitive hybrid poplar may be. The NPVR values are based on leasing land for hybrid poplar production given current agricultural rental values. Any project with a positive NPVR is financially viable to the firm, assuming the required capital is available at the assumed discount rate. The IRR and $\mathrm{B} / \mathrm{C}$ values are calculated based on this leasing situation. The OER values indicate the rotation age that maximizes the SEV and NPVR values. Table 3 shows that these rotation ages do not vary much - ranging from 18 to 24 years. Yet, the financial measures change significantly, depending on the assumptions being made, as discussed below.

\section{Base case}

The base case SEV suggests that the value of bare agricultural land for use in growing hybrid poplar is approximately $\$ 1681$ per hectare. In contrast, when considering the leasing costs to the firm, the NPVR drops to $-\$ 87$ per hectare. This result suggests that the leasing costs of agricultural land are such that this land is worth slightly more than the $\$ 1681$ per hectare land value based on using the land for hybrid poplar. However, if we were to use a discount rate of $3.6 \%$ instead of the $3.7 \%$ value assumed in the SEV and NPVR calculations, then the NPVR would be zero, indicating 3.6\% is the IRR for the investment, and the $\mathrm{B} / \mathrm{C}$ ratio would be 1 . This situation would represent the break-even point for the investments. Higher returns would be indicated by a higher IRR, a positive NPVR and a B/C ratio greater than one. Because of the interrelationships among the financial measures in Table 3, in the discussion that follows, we largely concentrate on describing the IRRs. ${ }^{12}$

\section{Scenarios 1 and 2: Changing the net stumpage value}

Scenario 1 in Table 3 shows that a $25 \%$ increase in net stumpage value raises the real IRR to $5.1 \%$ from its base case

\footnotetext{
${ }^{12}$ For scenarios 8 and 9 we describe NPVRs instead of IRRs. This is done because we are investigating impacts of changing the discount rate instead of solving for the discount rate as is done with IRRs.
}

value of $3.6 \%$. Scenario 2, however, shows that a $25 \%$ decrease in net stumpage price decreases the real IRR to $1.7 \%$. This variable shows a high degree of sensitivity.

\section{Scenarios 3 and 4: Changing the land rent}

Scenario 3 in Table 3 shows that a 25\% increase in land rent decreases the real IRR to $2.9 \%$ from its base case value of $3.6 \%$. Scenario 4 , however, shows that a $25 \%$ decrease in land rent increases the real IRR to $4.3 \%$. This relationship is shown in Fig. 3. Using policy to exploit the sensitivity of returns to land rents will be discussed later in this paper.

\section{Scenarios 5 and 6: Changing the total present value of silvicul- ture costs}

Scenario 5 in Table 3 shows that a 25\% increase in total present value of silviculture costs decreases the real IRR to $2.8 \%$ from its base case value of $3.6 \%$. Scenario 6 , however, shows that a $25 \%$ decrease in total present value of silviculture costs increases the real IRR to 4.7\%. This relationship is shown in Fig. 4.

Establishing short-rotation plantations is relatively new in Canadian boreal regions. This inexperience suggests the potential for increased efficiency as firms develop innovative new plantation systems applicable to local conditions. One potential cost saving relates to planting stock. The cost examples used in the base case are for planting rooted cuttings that have spent time developing roots in a greenhouse. In many areas, such as the Pacific Northwest, un-rooted poplar whips are planted successfully. This eliminates the greenhouse time required to root the cuttings, and also eases seedling storage, transportation, handling and planting - reducing the cost of all these activities. More research is needed, however, to determine if this technique will be successful in western Canadian boreal regions.

\section{Scenarios 7 and 8: Changing the real interest rate}

Scenario 7 in Table 3 shows that a $1.5 \%$ increase in real interest rate decreases the NPVR to $-\$ 700$ per hectare from its base case value of $-\$ 87$ per hectare. Scenario 8 , however, shows that a $1.5 \%$ decrease in real interest rate increases the NPVR to $\$ 1529$ per hectare.

Since the costs and benefits of plantation forestry occur at different times, interest rates, which measure how much more private firms value having money now versus having money in the future, have a significant impact on the financial viability of intensive forest management.

\section{Scenarios 9 and 10: Changing the growth rate}

Scenario 9 in Table 3 shows that a 27\% increase in stand volume at year 20 increases the real IRR to $5.1 \%$ from its base case value of $3.6 \%$. Scenario 10, however, shows that a $24 \%$ decrease in stand volume at year 20 decreases the real IRR to $2.1 \%$.

A relatively small increase in growth rate may be all that is necessary to make intensive forestry financially favourable on private land in Alberta. Given the diversifying effect poplar domestication could have on the Canadian forest industry, it might deserve to be a higher research priority. Opportunities to increase the level of research on hybrid poplar growth will be discussed later in this paper. 
Table 3. Sensitivity analysis.

\begin{tabular}{|c|c|c|c|c|c|}
\hline Scenarios & $\begin{array}{l}\text { SEV } \\
(\$ / \text { ha })\end{array}$ & $\begin{array}{l}\text { NPVR } \\
(\$ / h a)\end{array}$ & $\begin{array}{c}\text { Benefit/Cost } \\
\text { Ratio }\end{array}$ & $\begin{array}{c}\text { Real IRR } \\
(\%)\end{array}$ & $\begin{array}{c}\text { OER } \\
\text { (years) }\end{array}$ \\
\hline Base case & 1681 & -87 & 0.98 & 3.6 & 19 \\
\hline 1 & 2733 & 961 & 1.22 & 5.1 & 18 \\
\hline 2 & 664 & -1100 & 0.73 & 1.7 & 20 \\
\hline 3 & $\mathrm{n} / \mathrm{a}$ & -529 & 0.89 & 2.9 & 19 \\
\hline 4 & $\mathrm{n} / \mathrm{a}$ & 355 & 1.09 & 4.3 & 19 \\
\hline 5 & 1080 & -683 & 0.85 & 2.8 & 20 \\
\hline 6 & 2314 & 542 & 1.15 & 4.7 & 18 \\
\hline 7 & 564 & -700 & 0.79 & $\mathrm{n} / \mathrm{a}$ & 18 \\
\hline 8 & 4490 & 1529 & 1.24 & $\mathrm{n} / \mathrm{a}$ & 20 \\
\hline 9 & 3548 & 1017 & 1.25 & 5.1 & 20 \\
\hline 10 & 768 & -998 & 0.74 & 2.1 & 24 \\
\hline
\end{tabular}

\section{Specifications:}

Base case:

a. Net stumpage value $=\$ 28.69 / \mathrm{m}^{3}($ WRI 2000)

b. Total Present Value of Silviculture costs $=\$ 1$ 231/ha (Thomas and Kaiser 2003)

c. Land rent $=\$ 62 /$ ha $($ Thomas and Kaiser 2003)

d. Real interest rate $=3.7 \%$ (Buongiorno and Gilless 2003)

e. Yield parameters: $\mathrm{A}=275, \mathrm{n}=1.5$ and $\mathrm{k}=49.7$

NOTE: real IRR is solved for NPVR $=0$ with all other variables held constant

Alternative scenarios:

Scenario 1: Base case except $25 \%$ increase in net stumpage value (from $\$ 28.69 / \mathrm{m}^{3}$ to $\$ 35.86 / \mathrm{m}^{3}$ )

Scenario 2: Base case except $25 \%$ decrease in net stumpage value (from $\$ 28.69 / \mathrm{m}^{3}$ to $\$ 21.52 / \mathrm{m}^{3}$ )

Scenario 3: Base case except $25 \%$ increase in land rent (from $\$ 62 /$ ha to $\$ 77.50 / \mathrm{ha}$ )

Scenario 4: Base case except $25 \%$ decrease in land rent (from $\$ 62 /$ ha to $\$ 46.50 / \mathrm{ha}$ )

Scenario 5: Base case except 25\% increase in total present value of silviculture costs (from $\$ 1,231 /$ ha to $\$ 1,539 / \mathrm{ha}$ )

Scenario 6: Base case except $25 \%$ decrease in total present value of silviculture costs (from $\$ 1,231 /$ ha to $\$ 923 /$ ha)

Scenario 7: Base case except 1.5 percentage point increase in real interest rate (from $3.7 \%$ to $5.2 \%$ )

Scenario 8: Base case except 1.5 percentage point decrease in real interest rate (from $3.7 \%$ to $2.2 \%$ )

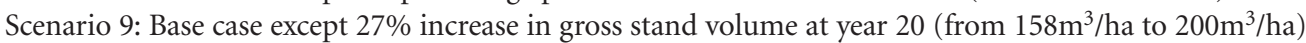

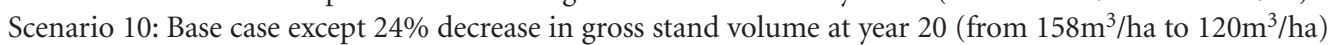

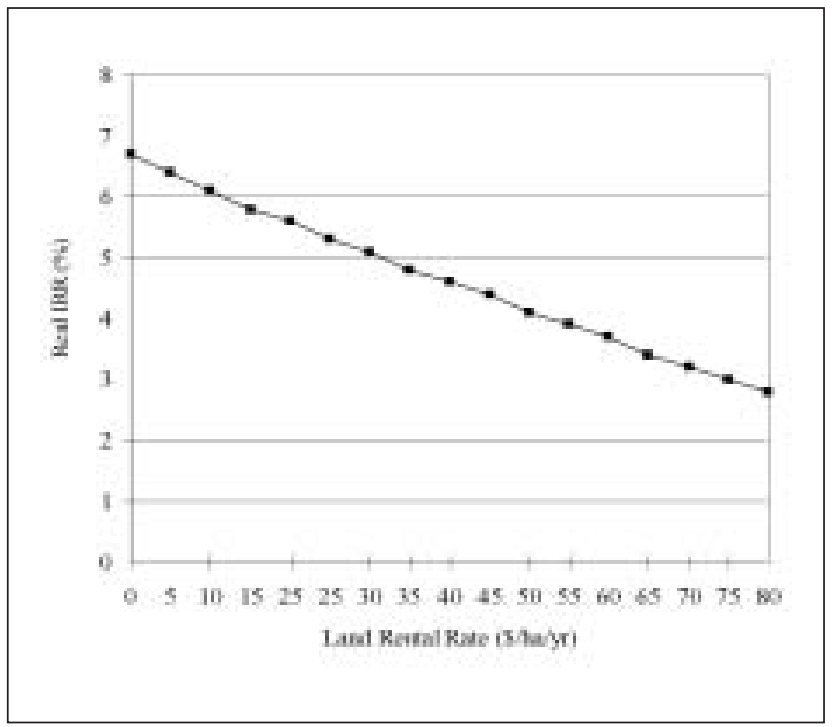

Fig. 3. Real IRR for base case scenario with different land rental rates.

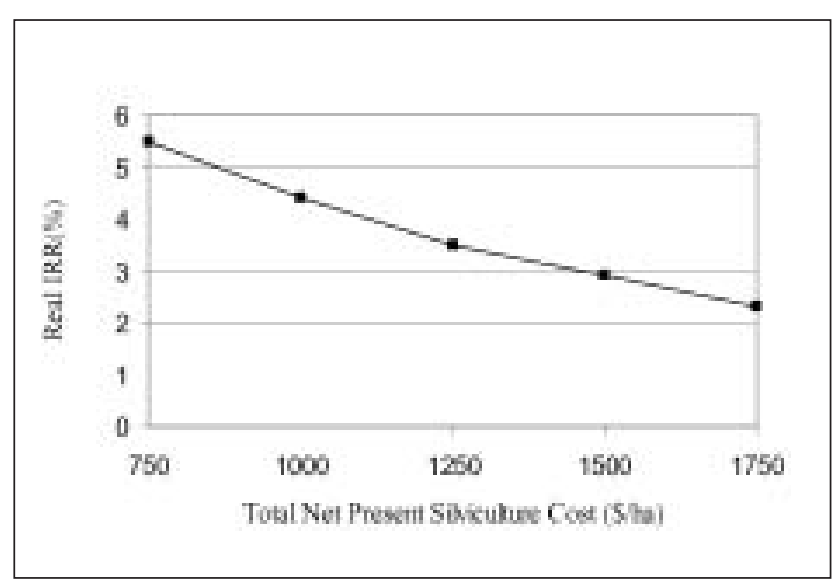

Fig. 4. Real IRR for base case scenario with different total net present silviculture costs. 


\section{Policy Considerations}

A number of policy considerations could influence the sensitivity analysis presented above. Below we consider: i) attempting to increase growth rates through increased research and innovation, ii) non-timber aspects of hybrid poplar plantations, iii) allowing hybrid poplar plantations on public land, and iv) allowing plantations on private land to be coupled with forest management agreements on public land.

\section{Increasing growth rates}

There is currently a large knowledge gap regarding the growth potential of hybrid poplar in Canada's boreal forest. There may be the opportunity to increase stand yield by increasing the planting density. Pulpwood hybrid poplar plantations in France planted at densities of 1900 stems per hectare produced stand growth rates almost double those estimated in this study (Benbrahim and Gavaland 2003). There is also speculation that boreal regions are nutrient-limited and may need fertilization to achieve higher growth rates (Weih 2004).

Further site-specific optimization of growing stock also seems likely. The base case yield curve estimate uses almost all of the available data, and thus represents a low risk aggregate yield curve for western Canadian boreal regions. It is important to understand, however, that the PFRA studies are essentially breeding trials. Many of the poorly performing clones used in this paper for the base case yield curve estimation would likely be eliminated from further breeding or commercialization. Eliminating these clones has a significant impact on the yield curve. In the 15-year age class, only the eight poorest performing clones out of the total of $26(31 \%)$ need to be eliminated for the growth curve to reach the upper bound of the $95 \%$ confidence interval, while the 25 -year age class requires the elimination of five out of the nine $(56 \%)$ clones. This suggests that the upper bound yield curve modeled in scenario 9, with its MAI of approximately 10 $\mathrm{m}^{3} /$ ha/year and real IRR of $5.1 \%$, might be more probable.

Geneticist Barb Thomas believes that simply selecting clones for western Canadian conditions, combined with appropriate silvicultural techniques, will achieve growth rates similar to scenario 9, and that once this is completed, further improvements to these clones could eventually push the upper bound MAI to approximately $12 \mathrm{~m}^{3} / \mathrm{ha}$ /year (Barb Thomas, Adjunct Professor, Department of Renewable Resources, University of Alberta, personal communication, 1 October 2004). This MAI represents a real IRR of approximately $6.2 \%$. But the size and heterogeneity of the western Canadian boreal region suggests that different clones might perform better in different regions, and achieving this performance over such a large area will likely require localized research and testing.

Another consideration is that the scope of this paper has been limited to considering traditionally bred or selected hybrid poplars. Yet, scientists have recently released the genome sequence for Populus, which represents the first sequence for a tree. By using biotechnology to build on this knowledge, tree breeders may be in a position to rapidly increase growth rates and decrease susceptibility to volume losses through gene selection and marker-aided selection of specific traits and/or processes (Tuskan et al.2003). But other forest regions and species will also likely gain from such technological advances, thereby raising the bar necessary for
Canada to compete internationally. Which regions gain more than others from these new technologies remains to be seen.

Despite the potential for such advances in Canada, it is possible that more research in hybrid poplar has not been conducted because policy constraints in Canada may be diminishing the benefits of increased knowledge (Nilsson et al. 2004). To remedy this, the government could make strategic policy changes that might provide industry with enough incentive to fund additional research. If a policy framework is in place such that firms can capitalize on information about improving growth rates, then more research will be conducted. Such potential policy changes are discussed below.

\section{Non-timber values}

The above calculations are based solely on the fibre values of forests; however, there are a number of other considerations that could favour or impede the expansion of hybrid poplar plantations in Canada's boreal forest. With Canada as a signatory to the Kyoto protocol, carbon values could enter into the financial viability of establishing plantations (e.g., van Kooten et al. 1999). At the time of writing, European Union emission permits are trading for $\$ 26.85 /$ tonne of carbon dioxide (Point Carbon 2005). With $1 \mathrm{~m}^{3}$ of hybrid poplar being approximately equal to 0.2 tonnes of carbon, these permits would increase our base case net stumpage value estimate to $\$ 34.06 / \mathrm{m}^{3}$, which would increase the real IRR from $3.6 \%$ to $4.7 \%$. This finding is supported by a recent study that estimated that for an MAI of $10 \mathrm{~m}^{3} / \mathrm{ha}$ /year and a carbon dioxide price of $\$ 25 /$ tonne, the apparent land availability for poplar plantations would be 310000 hectares in Western Canada and 20000 hectares in Eastern Canada (McKenney et al. 2004).

Moreover, poplar plantations could play an important role in fire and pest management. To the extent that deciduous species are more fire resistant than coniferous (Cumming 2001), as well as being resistant to the mountain pine beetle (NRCan 2005), there may be an added value to integrating them into forest level management plans.

Finally, there may be non-timber aspects of poplar plantations that decrease their value to society. Some groups may be opposed to establishing such plantations, especially if they are based on genomics rather than just traditional cross-breeding. The land use prior to the establishment of plantations may also play an important role in their acceptability. If indigenous forest land is replaced with exotic plantations, then the loss of biodiversity could be of concern. Such concerns may be alleviated if plantations are established on previous agricultural lands, or if other more sensitive areas of land are protected as a trade-off.

\section{Allowing hybrid poplar on public land: The crown white area in Alberta}

Recall that current provincial legislation prohibits foreign firms from purchasing private land in Alberta. But instead of renting private agricultural land, there is also the potential for firms to rent public agricultural land. Alberta's Crown white area is the band of public land that runs along the transition zone between agriculture and the boreal forest. Over 2.4 million hectares of this land is currently managed for agriculture as cattle grazing pasture (SRD 2003). It is likely that much of this pasture is able to sustain growth rates similar to the base case hybrid poplar MAI of $8 \mathrm{~m}^{3} /$ ha/year. One problem, how- 
ever, is that these pastures would initially require more site preparation to remove large stumps and rocks than most private agricultural land would require. However, since the current system for grazing leases only generates provincial revenues of approximately $\$ 1.67 /$ ha/year (SRD 2003), it is possible for hybrid poplar plantations to be financially viable even under higher site preparation costs.

For example, imagine pastureland in the Crown white zone that is leased to a timber company for $\$ 3.34 /$ ha/year, which is double the return from grazing. A 1994 study found that in Alberta the average land clearing costs - after all merchantable timber had been harvested - were approximately \$291/ha (Westworth and Associates 1994). Adjusting for the 1.8\% inflation that occurred between 1994 and 2004 (Bank of Canada 2004) yields a real cost of $\$ 347 /$ ha. Then, modeling the base case with land rent of $\$ 3.34 /$ ha/year and an increase in year zero silviculture costs of $\$ 347 / \mathrm{ha}$, the resulting real IRR is $5.0 \%$. Thus, this simple analysis suggests it could be possible for the government to set land rental rates for hybrid poplar higher than for grazing, while still ensuring hybrid poplar plantations are financially viable despite higher site preparation costs. This scenario becomes even more attractive when one considers that this additional site preparation should be required only once, thus allowing the government to increase the land rent for subsequent rotations.

\section{Coupling private land plantations to public forest management agreements}

The allowable cut effect (ACE) is an immediate increase in annual allowable cut (AAC) attributable to expected future increases in yield (Schweitzer et al. 1972). Regardless of whether plantations are established on private or public land, they increase expected future yield; and in settings where harvests are regulated by sustained yield, the ACE could be applied. For example, private land could be contractually coupled with public land to activate the ACE, thus allowing a firm to increase its AAC in existing timber from public lands because of increased productivity shown in poplar stands.

For firms to pursue the ACE, the profits experienced from the increase in AAC must offset the costs in establishing the plantations. These benefits to the ACE only arise because of the significant costs of the sustained yield constraint, and implementation of ACE policies may not be advisable because they may prolong the continuance of sustained yield policies (Luckert 2001). Although beyond the scope of this paper, the ACE is another possibility for making hybrid poplar plantations financially viable in the boreal forest, and its advantages and disadvantages should be explored further.

\section{Conclusions}

Roger Sedjo (1999), director of the forest economics and policy program at Resources for the Future, has stated that:

In recent years, there have been two impediments to plantations. The first relates to concerns over political stability and the unwillingness to make long-term financial commitments in an unstable political environment...The second impediment is found in the objections to plantations that are being made by some environmental groups. To overcome these objections it must be demonstrated that plantation forestry can serve a protective function for native forests, generate positive environmental benefits, and mitigate any associated environmental damages and social disruptions.

As a developed country, Canada is impacted little by the first impediment. This situation contrasts with many of the politically volatile subtropical countries where a large number of plantations are currently being established. The second impediment may not apply either, since under priority-use zoning there could be more land protected as ecological reserves. For such a change to occur, however, society would have to accept the environmental consequences of intensively managing exotic species - such as extensive herbicide use, decreased biodiversity, and increased water and nutrient usage - in exchange for increasing the amount of protected areas.

Indeed, the scale of this exchange could be grand. Consider, for example, that some countries produce almost $100 \%$ of the wood fibre for pulp and paper from industrial plantations (Sedjo 1999). If this were the case in Canada, using the base case assumption that plantations grow 2.5 times faster than native forest, this would imply that the Canadian forest industry could protect approximately $60 \%$ of the current pulpwood and strand-board producing landbase while maintaining current output of forest products.

There is currently some momentum within the government towards more serious consideration of plantations. In 1999, the Canadian Council of Forest Ministers launched the program Forests 2020, with the intent to "make better use of fast-growing, high-yield plantations and intensive silviculture, along with existing forest management practices...to help Canada meet increasing global demand for wood products, while ensuring an acceptable level of forest ecosystem conservation and increased local benefits from all forest resources (CCFM 2001)." More recently, a new initiative of this programme is "...to demonstrate the value of fast-growing plantations across Canada and evaluate options that could attract investments in future Canadian plantations, by taking advantage of the combined benefits of both wood fibre and carbon values (CCFM undated)." However, as this paper has shown, only exotic species are likely to produce positive financial returns, and information available to assess financial prospects of these species is scarce. Moreover, a number of policy considerations could currently be blocking a move towards plantation forestry.

Given these limitations, the answer to the question posed by the title appears to be "maybe." Indeed, a priority-use zoning system might address the challenges facing Canada's forest industry. But this analysis suggests that within Alberta, intensive forestry using hybrid poplar is in a financial "grey area." Therefore, policy changes, such as those listed above, may be required before the forest industry transitions towards a priority-use zoning system using exotic species in the intensive zones. This opinion is supported by a recent review paper in the Canadian Journal of Forest Research, which concluded that "the major barriers for a rapid development of short-rotation forestry, especially in the major agricultural regions of the boreal zone, appear not to be climatic, technical, or environmental constraints, but rather sociopolitical issues (Weih 2004).” 


\section{Acknowledgements}

This work was supported by the Social Sciences and Humanities Research Council of Canada, the University of Alberta $\mathrm{PhD}$ Scholarship, Alberta-Pacific Forest Industries Inc., and Weyerhaeuser Company Limited. For their helpful comments, thanks are due to Glen Armstrong, Grant Hauer, Andrew Swan, Barb Thomas, Pat Wearmouth and anonymous reviewers. The authors are responsible for all remaining errors, and the opinions expressed in this paper.

\section{References}

Agricultural and Recreational Land Ownership Act, Foreign Ownership of Land Regulations 160/79. 1979. Alberta Statutes and Regulations, Province of Alberta, Queen's Printer, Edmonton, Alberta [online]. Available from http://www.qp.gov.ab.ca/ documents/Regs/1979_160.cfm?frm_isbn=0779705793 [cited 26 November 2004].

Bank of Canada. 2004. Consumer price index [online]. Available at http://www.bankofcanada.ca/en/cpi.htm [cited 29 July 2004].

Benbrahim, M. and A. Gavaland. 2003. A new stem taper function for short-rotation poplar. Scand. J. For. Res. 18: 377-383.

Binkley, C.S. 1997. Preserving nature through intensive plantation forestry: the case for forestland allocation with illustrations from British Columbia. For. Chron. 73: 553-559.

Bradshaw, H.D. Jr. and S.H. Strauss. 2001. Breeding strategies for the $21^{\text {st }}$ Century: domestication of poplar. In D.I. Dickmann, J.G. Isebrands, J.E. Eckenwalder and J. Richardson (eds.). Poplar Culture in North America. Part B, Chapter 14. pp. 383-394. NRC Research Press, National Research Council of Canada, Ottawa, ON. Buongiorno, J. and J.K. Gilless. 2003. Decision methods for forest resource management. Academic Press, Elsevier Science, Oxford, UK. 439 p.

CCFM. 2001. Forests 2020: What is it and where is it going? Canadian Council of Forest Ministers [online]. Available at http://www.ccfm.org/forest2020/about_e.html [cited 17 September 2004]

CCFM. undated. Forests 2020 - a dialogue with Canadians. Canadian Council of Forest Ministers [online]. Available at http:// www.ccfm.org/forest2020/index_e.html [cited 10 October 2006].

Cumming, S.G. 2001. A parametric model of fire-size distribution. Can. J. For. Res. 1: 1297-1303.

Environment Canada. 2004. Canadian Climate Normals [online]. Available at http://www.climate.weatheroffice.ec.gc.ca [cited 15 October 2005].

FAO. 2000. The state of the world's forests. Rome. Food and Agriculture Organization of the United Nations.

Forests Act, Timber Management Regulations 60/73. 1973. Alberta Statutes and regulations, Province of Alberta, Queen's Printer, Edmonton, Alberta [online]. http://www.qp.gov.ab.ca/documents/ Regs/1973_060.cfm?frm_isbn=077972724X [cited 26 November 2005].

Gladstone, W.T. and F.T. Ledig. 1990. Reducing pressure on natural forests through high-yield forestry. For.Ecol.Manage. 35: 69-78.

Harou P.A. 1985. On a social discount rate for forestry. Can. J. For. Res. 15(5): 927-934.

Heilman, P.E. 1999. Planted forests: poplars. New For. 17: 89-93.

Hunter, M.L. (ed.). 1999. Maintaining biodiversity in forest ecosystems. Cambridge University Press, Cambridge, UK. 698 p.

Hunter, M.L. and A. Calhoun. 1996. A triad approach to land-use allocation. In R.C. Szaro and D.W. Johnson (eds.). Biodiversity in managed landscapes. pp. 477-491. Oxford University Press, New York, NY.

Kozak, A. 1988. A variable-exponent taper equation. Can. J. For. Res. 18: 1363-1368.

Larsson, S. and K. Danell. (eds.). 2001. Science and the management of boreal forest biodiversity. Scand. J. For. Res. Suppl. 3. Taylor \& Francis, Oslo, Norway. 123 p.
Limerick, P.N. 2002. Forestry and modern environmentalism: ending the cold war. J. For. 100(8): 46-50.

Luckert, M.K. 2001. Welfare implications of the allowable cut effect in the context of sustained yield and sustainable development forestry. J. of For. Econ. 7(3): 203-224.

Luckert, M.K. and J. Bernard. 1993. What is the value of standing timber?: Difficulties in merging theory with reality. For. Chron. 69(6): 680-685.

McKenney, D.W., D. Yemshanov, G. Fox, and E. Ramlal. 2004. Cost estimates for carbon sequestration from fast growing poplar plantations in Canada. For. Pol. and Econ. 6: 345-358.

Messier, C. 2003. The triad approach to forest management. Interview of C. Messier. Audio recording. Episode No.64, Innovation Alberta.

Ministry of Finance. 2005. Investing in the next Alberta: fiscal plan 2005-2008. Government of Alberta [online]. Available at http://www. finance.gov.ab.ca/publications/budget/budget2005/fiscal.html\#9 [cited 5 May 2005].

Nilsson, G., M.K. Luckert, G.W. Armstrong, G.K. Hauer, and M.J. Messmer. 2004. Approaches to setting forestry research priorities: Considering the benefits of reducing uncertainty. For. Chron. 80(3): 384-390.

Natural Resources Canada (NRCan). 2005. Silviculture and the Mountain Pine Beetle. Natural Resources Canada [online]. Available at http://www.pfc.forestry.ca/entomology/mpb/management/silviculture/introduction_e.html [cited 5 May 2005].

Ontario Ministry of Natural Resources (OMNR). 1991. A grower's guide to hybrid poplar. Ontario Ministry of Natural Resources. Appendix 10.2.

Pearse, P.H. 1990. Introduction to forestry economics. University of British Columbia Press, Vancouver, BC. 226 p.

Peterson, E.B., Y.H Chain and J.B. Cragg. 1970. Aboveground standing crop, leaf area, and caloric value in an aspen clone near Calgary, Alberta. Can. J. Bot. 48: 1459-1469.

Point Carbon. 2005. Price information, EU emissions trading scheme [online]. Available at http://www.pointcarbon.com/category.php?categoryID=745 [cited 9 May 2005].

Prairie Farm Rehabilitation Administration (PFRA). 2001. Project Summaries - 2000 and 2001. pp. 50-55. Agri-Food and Agriculture Canada.

Pullman, G.S., J. Cairney and G. Peter. 1998. Clonal forestry and genetic engineering: where we stand, future prospects, and the potential impacts of mill operations. TAPPI J. 81: 57-64.

Rodrigues, P.M.J., M.K. Luckert, V. Lieffers and V. Adamowicz. 1998. Economic analysis of ecologically based mixedwood silviculture at the stand level. Project report to the

Environmental Protection and Enhancement Fund, Alberta Environmental Protection. $122 \mathrm{p}$.

Saint-André, L., J.M. Leban, F. Houiller and R. Daquitaine. 1999. Comparison between two stem taper equations, and validation on an independent sample. Case study of Norway Spruce (Picea abies Karst.). Ann. For. Sci. 56: 121-132.

Schneider, R.R., J.B. Stelfox, S. Boutin and S. Wasel. 2003. Managing the cumulative impacts of land uses in the Western Canadian Sedimentary Basin: a modeling approach. Conservation Ecology 7(1): 8 [online] hppt://www.consecol.org/vol7/iss1/art8 [cited 9 May 2005].

Schweitzer, D.L.R., R.W. Sassaman and C.H. Schallau. 1972. Allowable cut effect: some physical and economic implications. J. of For. 70: 415-418.

Sedjo, R.A. 1999. The potential of high-yield plantation forestry for meeting timber needs. New For. 17: 339-359.

Sedjo, R.A. 2003. Biotech and planted trees: some economic and regulatory issues. AgBioForum, 6(3): 113-119.

SRD. 2003. Grazing statistics for public lands. Department of Sustainable Resource Development, Government of Alberta [online]. Available at http://www3.gov.ab.ca/srd/land/APL_ Grazing_Stats.html [cited 28 July 2004]. 
Stevenson, M.G. and J. Webb. 2003. Just another stakeholder? First Nations and sustainable forest management in Canada's Boreal Forest. Chapter 3. In P.J. Burton, C. Messier, D.W. Smith and W.L. Adamowicz (eds.). Towards Sustainable Management of the Boreal Forest. pp. 65-112. NRC Research Press, Ottawa, ON.

Tardif, M.L. 1994. Update of short rotation intensive culture in Canada. Paper presented at the Mechanization in Short Rotation, Intensive Culture Forestry Conference, Mobile, AL, March 1-3, 1994. Natural Resources Canada, Alternative Energy Division, Ottawa, ON [online]. Available at http://www.woodycrops.org/ mechconf/tardiff.html

Thomas, B. and C. Kaiser. 2003. Poplar farming in the boreal forest transition zone: Alberta-Pacific Forest Industries Inc. In Proceedings of Poplar Council of Canada Annual Meeting, September 17, 2003 [online]. Available at http://www.poplar.ca/pdf/thomas.pdf [cited 29 November 2006].

Tomberlin, D. and J. Buongiorno. 2001. Timber plantations, timber supply, and conservation. In M. Palo, J. Uusivori, and G. Mery (eds.). World Forests, Markets, and Policies. pp. 207-17. Kluwer Academic Publishers, London.

Tuskan, G.A., S.P. DiFazio and T. Teichmann. 2003. Poplar genomics is getting popular: the impact of the poplar genome project on tree research. Plant Bio. 5: 1-3 van Kooten, G.C., E. Krcmar-Nozic, B. Stennes and R. van Gorkom. 1999. Economics of fossil fuel substitution and wood product sinks when trees are planted to sequester carbon on agricultural lands in western Canada. Can. J. For. Res. 29: 1669-1678.

Vincent, J.R. and C.S. Binkley. 1993. Efficient multiple-use forestry may require land-use specialization. Land Econ. 69: 370-376.

Wear, D.N. and B.C. Murray. 2004. Federal timber restrictions, interregional spillovers, and the impact on US softwood markets. J. of Env. Econ. and Mgmt. 47: 307-330.

Weih, M. 2004. Intensive short rotation forestry in boreal climates: present and future perspectives. Can. J. For. Res. 34: 1369-1378.

Westworth, D.A. and Associates. 1994. Aspen woodlot feasibility study. Canada-Alberta Partnership Agreement in Forestry. Pub. No. I/529. $103 \mathrm{p}$.

WRI. 2000. North American Wood Fiber Review. Wood Resources International [online]. Available at http://www.wri-ltd.com/wood fibre.html [cited 29 July 2004].

WRI. 2003. Wood Resource Quarterly. Wood Resources International [online]. Available at http://www.wri-ltd.com/woodfibre. html [cited 29 July 2004]. 